\title{
Activity limitation in elderly people in the European context of gender inequality: a multilevel approach
}

\author{
Limitação de atividade em idosos no contexto Europeu \\ de desigualdade de gênero: uma abordagem multinível
}

André Luiz Barbosa de Lima ${ }^{1}$

Albert Espelt ${ }^{2}$

Kenio Costa de Lima ${ }^{1}$

Marina Bosque-Prous ${ }^{2}$

${ }^{1}$ Programa de Pós-

Graduação em Saúde

Coletiva, Universidade

Federal do Rio Grande

do Norte. Av. Hermes da

Fonseca s/n, Lagoa Nova 59084-100 Natal RN

Brasil.allima@aspb.cat

${ }^{2}$ Faculty of Health Sciences,

Open University of

Catalonia. Barcelona Spain.
Abstract The objective of the present study was to examine the magnitude of gender differences in activity limitations among the elderly, and the effect of the health and social individual factors and the context of social gender inequality in Europe. Cross-sectional design was performed. The study population included residents aged 60 years or over from 17 countries that participated in the Survey of Health, Ageing and Retirement in Europe conducted in 2010-13 $(n=49,685)$. Gender differences in activity limitation in each country was estimated. For multilevel analysis adjusted linear mixed effect models were used, where the intercept and 'sex' were considered random effects, with the 95\% confidence intervals. The activity limitation index was created from a two parameter logistic combined models of item response theory. The average activity limitation index was significantly higher in women, $\widehat{\gamma}_{10}=\widehat{\beta}_{1 j}=0.36, p$ $<0.001$ ), and was then controlled by individual and contextual factors, while the extent of these differences varied among countries. The European countries with the greatest gender differences in activity limitations were those with the greatest social gender inequalities, with women presenting a significant disadvantage.

Key words Statistics on sequelae and disability, Aged, Multilevel analysis, Gender and health
Resumo O presente estudo objetivou examinar as magnitudes das diferenças de gênero nas limitações de atividades entre idosos, e o efeito dos fatores sociais e de saúde e o contexto de desigualdades sociais de gênero na Europa. Foi realizado um estudo descritivo retrospectivo de corte transversal. A população do estudo incluiu residentes com 60 ou mais anos de idade de 17 países que participaram do Inquérito de Saúde, Envelhecimento e Reforma na Europa, conduzido em 2010-13 ( $n=$ 49.685). Foram estimadas as diferenças de gênero nas limitações de atividades para cada país. Para a análise multinível foram ajustados modelos mistos lineares, onde o intercepto e o 'sexo' foram considerados efeitos aleatórios, com intervalos de confiança de 95\%. O indice de limitação de atividades foi criado a partir de modelos combinados de dois parâmetros logisticos, na teoria de resposta ao item. A média do indice de limitação de atividades foi significativamente mais alta em $\mathrm{mu}$ lheres, $\left(\widehat{\gamma}_{10}=\widehat{\beta}_{1 j}=0,36, p<0,001\right)$, controlada por fatores individuais e contextuais, enquanto a extensão destas diferenças de gênero variou entre os países. Os países com as maiores diferenças de gênero nas limitações de atividade foram aqueles com as maiores desigualdades sociais de gênero, com as mulheres apresentando uma desvantagem significativa.

Palavras-chave Estatísticas de sequelas e incapacidade, Idoso, Análise multinível, Gênero e saúde 


\section{Introduction}

Projections indicate that the population of elderly people with functional disabilities will grow rapidly over a short period of time. In this way, assessment of functional capacity is a useful tool for assessing the health of the elderly, many of whom have several chronic diseases of varying severity, with different impacts on daily life ${ }^{1,2}$.

The measurement of activity limitations incorporates one of the most important negative aspects of functionality, especially among elderly people $\mathrm{e}^{3,4}$. Disability among elderly persons is associated with several factors at individual and contextual levels, such as a diminished quality of life, rising costs of health care, long periods of care and social exclusion or the inability to actively participate in society ${ }^{5,6}$.

A number of scientific propositions state that the probability of an individual presenting comorbidities increases with longer life and leads to higher prevalence of disability ${ }^{7-9}$. Therefore, the elderly population represents a significant problem for society to overcome, in that greater years of life are not lived in healthy and independent conditions ${ }^{10,11}$. However, older people can achieve a healthy and active aging, through individual and personal effort and supported by social ties, despite the health-related, financial and social declines associated with aging ${ }^{12}$.

According to Eurostat, the ratio of older people (65 and older) or older people who are dependent because of senility in Europe, in relation to people of working age is expected to double from $17 \%$ to $30 \%$ by $2060^{13}$. Basically, the high prevalence of disability among women compared to men is due to a combination of a higher incidence and a greater survival rate, resulting in a low recovery and mortality rate among women with disabilities ${ }^{14-16}$. In this regard, it is important that policies to promote active aging consider gender differences and socioeconomic factors ${ }^{17}$. Furthermore, it is necessary to distinguish between sex and gender. Sex refers to biological and physiological differences between women and men such as hormones, genitalia or chromosomes. Gender refers to the characteristics of women and men that vary from society to society and are socioculturally and historically constructed ${ }^{18,19}$.

It should be noted that epidemiological studies, which jointly address the individual and contextual factors of activity limitation, more adequately reflect the impact of disease on the quality of life of elderly people. This study, therefore, aimed to examine the magnitude of gender differences in activity limitations among the elderly, the effect of health and social individual factors, and the context of social gender inequality in Europe.

\section{Methods}

The present study featured a cross-sectional design, based on the databases of the Survey of Health, Ageing and Retirement in Europe (SHARE) project for 17 European countries (Austria, Belgium, Czech Republic, Denmark, Estonia, France, Germany, Hungary, Italy, Luxembourg, Netherlands, Poland, Portugal, Spain, Slovenia, Sweden and Switzerland). Data from Hungary, Poland and Portugal was collected in 2011-12, while information from the other countries was collected in 2013. The study population consisted of 49,685 people aged 60 years or over.

Calibrated individual weighting of the sampling design was considered, allowing unbiased estimators of the parameters of the populations to be obtained, and solving non-response and sample attrition issues. The percentage of individuals excluded from the study due to a lack of data for any of the individual variables was $2.1 \%$.

The dependent variable, known as the activity limitation index (ALI), was established through the item response theory (IRT) used in this study and was composed of four dimensions: (i) basic activities of daily living (ADL); (ii) instrumental activities of daily living (IADL); (iii) mobility; and (iv) depression profile. Chart 1 shows the variables that composed the dimensions of the ALI and those included in the functional capacity measurement processes ${ }^{20-22}$. The SHARE questionnaires asked whether the individual had any difficulty with ADL or IADL tasks or those of the mobility dimension due to physical, mental, emotional or memory problems, excluding any difficulties that were expected to last less than three months.

The main independent variable was 'sex', as a marker of gender inequality marker, bearing in mind that the concept of gender refers to the social construction of sex. The other independent variables included in the analysis were (i) age (years), (ii) educational level (dichotomous: lower secondary or less; upper secondary or more), (iii) self-perceived health (dichotomous: excellent, very good or good, fair or poor), (iv) chronic medication (dichotomous: no medication; one or more medication) and (v) burden of chronic diseases (dichotomous: one or less; two or more). 
Chart 1. Description of the dimensions of activity limitation index.

\begin{tabular}{|c|c|}
\hline Dimension & Item \\
\hline $\begin{array}{l}\text { Basic } \\
\text { activities of } \\
\text { daily living } \\
\text { (ADL) }\end{array}$ & $\begin{array}{l}\text { Dressing, including putting on socks } \\
\text { and shoes } \\
\text { Bathing or showering } \\
\text { Eating, such as cutting up food } \\
\text { Getting in and out of bed } \\
\text { Using the toilet, including getting up } \\
\text { or down }\end{array}$ \\
\hline $\begin{array}{l}\text { Instrumental } \\
\text { activities of } \\
\text { daily living } \\
\text { (IADL) }\end{array}$ & $\begin{array}{l}\text { Preparing a hot meal } \\
\text { Shopping for groceries } \\
\text { Making telephone call } \\
\text { Taking medications } \\
\text { Doing work around the house or } \\
\text { garden } \\
\text { Managing money, such as paying } \\
\text { bills and keeping track of } \\
\text { expenses }\end{array}$ \\
\hline Mobility & $\begin{array}{l}\text { Walking } 100 \text { meters } \\
\text { Sitting two hours } \\
\text { Getting up from chair } \\
\text { Climbing several flights of stairs } \\
\text { Climbing one flight of stairs } \\
\text { Stooping, kneeling or crouching } \\
\text { Reaching or extending arms above } \\
\text { shoulder } \\
\text { Pulling or pushing large objects } \\
\text { Lifting or carrying objects weighing } \\
\text { more than } 5 \text { kilos } \\
\text { Picking up a small coin from a table }\end{array}$ \\
\hline $\begin{array}{l}\text { Depression } \\
\text { profile }\end{array}$ & $\begin{array}{l}\text { Based in EURO-D symptoms: } \\
\text { Depression } \\
\text { Pessimism } \\
\text { Suicidality } \\
\text { Guilt } \\
\text { Sleep } \\
\text { Interest } \\
\text { Irritability } \\
\text { Appetite } \\
\text { Fatigue } \\
\text { Concentration } \\
\text { Enjoyment } \\
\text { Tearfulness }\end{array}$ \\
\hline
\end{tabular}

Source: SHARE Waves 4/5, 2010-2013.

The variables of the ILA dimensions ( $a d l$, iadl, mobility and eurod), self-perceived health (sphus) and the number of chronic diseases (chronic) are part of the gv_health module (SHARE project), which contains the health generated variables and index related to the physical and mental health of respondents ${ }^{23}$.

The independent context variable at country level was the gender inequality index (GII) proposed by the United Nations Development Programme ${ }^{24}$. The GII reflects social gender inequalities in three dimensions: reproductive health, empowerment and economic activity. Reproductive health is measured by maternal mortality and adolescent fertility; empowerment is measured by the proportion of seats held by women parliamentarians and attainment of secondary and higher education by gender; and economic activity is measured by the participation in the labour market rate for women and men. The GII, then, can be interpreted as losses in human development due to inequality between the achievements of women and men in all three dimensions. The GII varies between 0 and 1 with higher values signifying higher levels of social gender inequality.

\section{Analysis}

Descriptive statistics were calculated for the individual variables and the ALI.

All the dimensions of the ALI were based on the two logistic parameter combined multiple IRT models, using structural equation modelling, respecting dimensionality of latent space and stochastic local independence. The ALI comprises a scale ranging from -3 to +3 , where negative values closer to -3 indicate a low level of latent trait and values closest to +3 indicate more serious activity limitations among elderly people.

To estimate the multilevel model three multivariate analysis statistical models with robust variance were adjusted: (i) Model I: to estimate the variation in the global average of the product variable considering the two levels of analysis, adjusted for 'sex'; (ii) Model II: other explanatory variables were added to the previous model on an individual level; and (iii) Model III: insertion of 'gender inequality' contextual variable to model II. A multilevel linear regression model was also adjusted, where the intercept and 'sex' were considered as random effects on all models, using the $95 \%$ confidence interval (95\% CI). Statistical analyses were conducted using STATA 14.1 and HLM7.

\section{Results}

\section{Descriptive statistics}

In the present study, the average age of the elderly persons was 72 (SD 8.0) years. A total of $17 \%$ were 80 or older, and $84 \%$ presented at least 
some activity limitation. Table 1 presents a description of the ALI averages for each individual variable and country.

On average, activity limitation among women was greater than among men, as well among older elderly persons. However, a higher educational level represented an important protective factor. In terms of self-perceived health, reports of fair or poor health were associated with greater activity limitations. A greater burden of disease and the use of chronic medication were also factors that were strongly related to greater activity limitations. Among countries, Hungary had the greatest activity limitation among elderly people,

Table 1. Descriptive statistics of the average activity limitation index.

\begin{tabular}{|c|c|c|c|}
\hline \multirow{2}{*}{ Variables } & \multicolumn{2}{|c|}{ Total } & \multirow{2}{*}{ ALI mean $\left(95 \% \mathrm{CI}^{\star}\right)$} \\
\hline & $\mathbf{n}$ & $\%$ & \\
\hline \multicolumn{4}{|l|}{ Sex } \\
\hline Men & 22,561 & 45.4 & $-0.22(-0.23--0.20)$ \\
\hline Women & 27,124 & 54.6 & $0.16(0.15-0.18)$ \\
\hline \multicolumn{4}{|l|}{ Age range (years) } \\
\hline $60-64$ & 12,244 & 24.64 & $-0.29(-0.31--0.28)$ \\
\hline $65-69$ & 11,746 & 23.64 & $-0.26(-0.28--0.23)$ \\
\hline $70-74$ & 9,488 & 19.10 & $-0.08(-0.11--0.06)$ \\
\hline $75-79$ & 7,347 & 14.79 & $0.15(0.12-0.18)$ \\
\hline $80+$ & 8,860 & 17.83 & $0.60(0.57-0.63)$ \\
\hline \multicolumn{4}{|l|}{ Educational level } \\
\hline Lower secondary or less & 21,786 & 44.62 & $0.23(0.21-0.25)$ \\
\hline Upper secondary or more & 27,036 & 55.38 & $-0.19(-0.20-0.18)$ \\
\hline \multicolumn{4}{|l|}{ Health self-perceived } \\
\hline Excellent, very good or good & 27,599 & 55.71 & $-0.44(-0.45--0.43)$ \\
\hline Fair or poor & 21,939 & 44.29 & $0.55(0.54-0.57)$ \\
\hline \multicolumn{4}{|l|}{ Chronic medication } \\
\hline None & 12,075 & 24.30 & $-0.49(-0.51--0.46)$ \\
\hline One or more & 37,610 & 75.70 & $0.15(0.14-0.17)$ \\
\hline \multicolumn{4}{|l|}{ Disease burden } \\
\hline Less than two & 22,373 & 45.20 & $-0.39(-0.40--0.37)$ \\
\hline Two or more & 27,121 & 54.80 & $0.31(0.29-0.33)$ \\
\hline \multicolumn{4}{|l|}{ Country } \\
\hline Germany (GER) & 3,637 & 7.32 & $-0.04(-0.07--0.01)$ \\
\hline Austria (AUS) & 3,159 & 6.36 & $-0.11(-0.15--0.07)$ \\
\hline Belgium (BEL) & 3,703 & 7.45 & $0.01(-0.03-0.05)$ \\
\hline Denmark (DEN) & 2,656 & 5.35 & $-0.28(-0.31--0.24)$ \\
\hline Slovenia (SLO) & 2,024 & 4.07 & $0.03(-0.02-0.08)$ \\
\hline Spain (SPA) & 4,708 & 9.48 & $0.16(0.11-0.22)$ \\
\hline Estonia (EST) & 4,378 & 8.81 & $0.25(0.22-0.27)$ \\
\hline France (FRA) & 3,237 & 6.52 & $0.02(-0.02-0.06)$ \\
\hline Netherlands (NDL) & 2,960 & 5.96 & $-0.28(-0.31--0.24)$ \\
\hline Hungary (HUN) & 2,024 & 4.07 & $0.34(0.26-0.43)$ \\
\hline Italy (ITA) & 3,424 & 6.89 & $0.12(0.07-0.17)$ \\
\hline Luxembourg (LUX) & 990 & 1.99 & $0.04(-0.02-0.09)$ \\
\hline Poland (POL) & 1,353 & 2.72 & $0.26(0.20-0.31)$ \\
\hline Portugal (POR) & 1,356 & 2.73 & $0.23(0.10-0.36)$ \\
\hline Czech Republic (CZE) & 4,253 & 8.56 & $-0.03(-0.07-0.00)$ \\
\hline Sweden (SWE) & 3,680 & 7.41 & $-0.27(-0.29--0.24)$ \\
\hline Switzerland (SWI) & 2,143 & 4.31 & $-0.35(-0.38--0.32)$ \\
\hline
\end{tabular}


whereas Swiss elderly people suffered less activity limitation.

\section{Relationship of gender difference and restriction of activities}

As shown in Figure 1, gender differences in activity limitations among elderly persons were observed among the European countries evaluated, after adjustment for other variables. The extent of gender differences in activity limitation for each country was displayed, and were found to be greater in Eastern European countries (Hungary, Poland and Estonia).

\section{Multilevel analysis}

\section{Associations in activity limitations and social gender inequality}

In Model I, the intercept of -0.20 represents the average activity limitation index among men in European countries, according to the data presented in Table 2. The intercepts for 17 European countries varied around the average intercept, indicating statistically significant variation within and between countries. In addition, 19\% of the total variance of the activity limitation index was attributed to differences between countries relating to their averages. The final multilevel model explained $67 \%$ of the variance in gender differences between European countries, with interactions between levels not considered. Compared to model I, the addition of the other level 1-individual variables and the social gender inequality contextual factor at level 2 changed the residual variance by a factor of $0.656 / 0.847=0.774$ in model III, which resulted in a variance represented by $1-0.774=0.226$.

In the final model, women were significantly more affected by activity limitation, $\widehat{\gamma}_{10}=\widehat{\beta}_{1 j}=$ $0.36, p<0.001$ while the effect of the gender gap varied between countries. Advanced age was also significantly associated with activity limitations in elderly people. Moreover, regardless of sex and age, elderly people who perceived their health to be "fair or poor", consumed more than one medication and suffered from two or more diseases were associated with greater activity limitation. On the other hand, a higher educational level was a protective factor. In the context level, greater

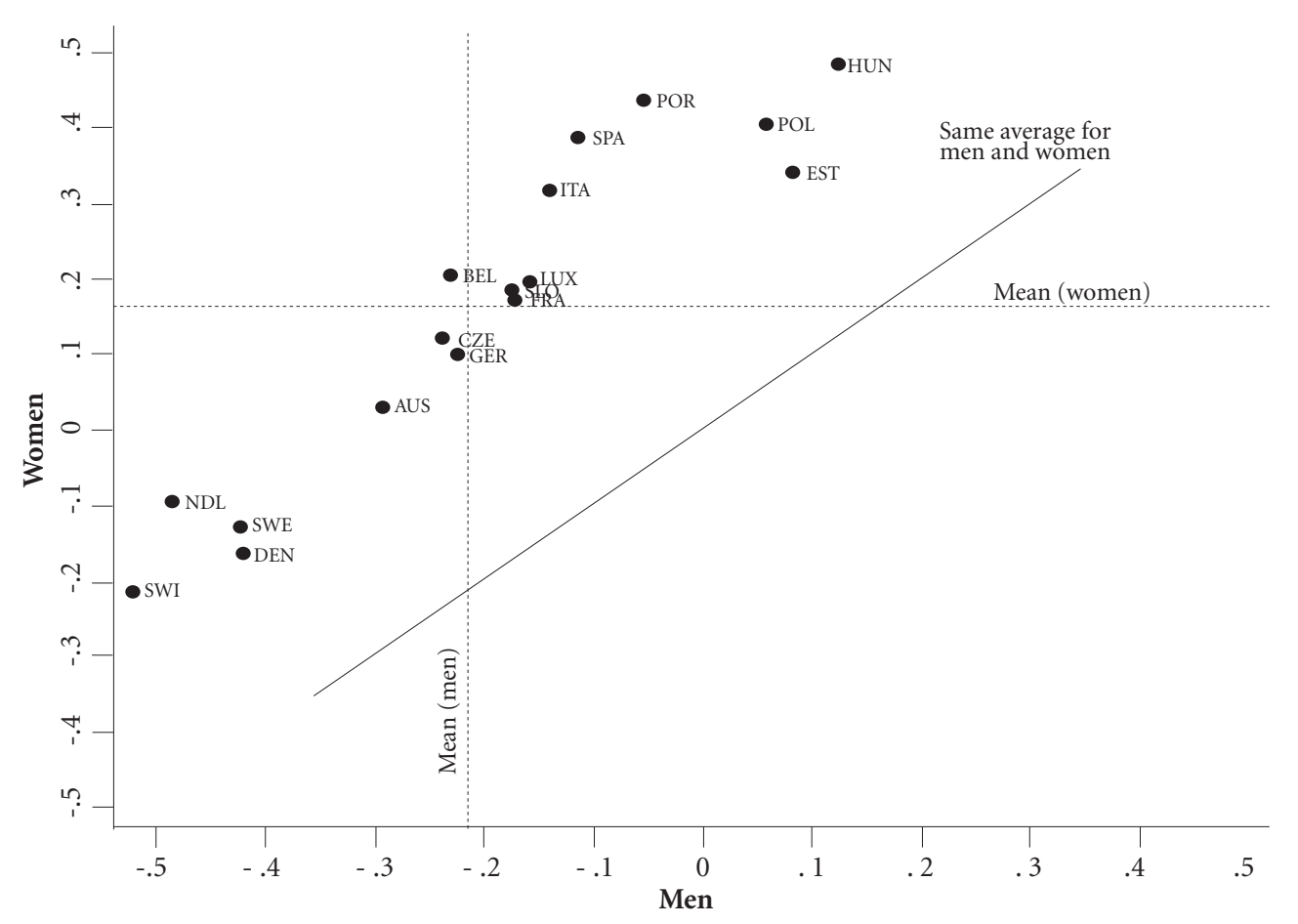

Figure 1 - Scatter plot of the average activity limitation indexes adjusted among elderly women and men aged 60 or over years, European countries. Larger index values represent less favourable conditions of activity limitation. Source: SHARE Waves 4/5, 2010-13. 
Table 2. Estimates of individual-level and country-level linear mixed effects obtained from multilevel analysis of activity limitation index in a sample of the elderly people aged 60 or over years from 17 countries participating in the SHARE project 2010-13.

\begin{tabular}{|c|c|c|c|c|c|c|}
\hline & \multicolumn{2}{|c|}{ Model I } & \multicolumn{2}{|c|}{ Model II } & \multicolumn{2}{|c|}{ Model III } \\
\hline & $\begin{array}{c}\text { Coefficient } \\
\left(\mathrm{SE}^{\star *}\right)\end{array}$ & $\begin{array}{c}\text { p- } \\
\text { value }\end{array}$ & $\begin{array}{l}\text { Coefficient } \\
\left(\mathrm{SE}^{\star *}\right)\end{array}$ & $\begin{array}{c}\text { p- } \\
\text { value }\end{array}$ & $\begin{array}{l}\text { Coefficient } \\
\left(\mathrm{SE}^{\star *}\right)\end{array}$ & $\begin{array}{c}\text { p- } \\
\text { value }\end{array}$ \\
\hline \multicolumn{7}{|l|}{ Individual variables } \\
\hline \multicolumn{7}{|l|}{ Sex (Men): } \\
\hline Women & 0.36 & $<0.001$ & 0.23 & $<0.001$ & 0.23 & $<0.001$ \\
\hline Age (years) & & & 0.03 & $<0.001$ & 0.03 & $<0.001$ \\
\hline \multicolumn{7}{|c|}{ Educational level (Lower secondary or less): } \\
\hline Upper secondary or more & & & -0.11 & $<0.001$ & -0.11 & $<0.001$ \\
\hline \multicolumn{7}{|c|}{$\begin{array}{l}\text { Health self-perceived (Excellent, very good, } \\
\text { good): }\end{array}$} \\
\hline Fair or poor & & & 0.72 & $<0.001$ & 0.73 & $<0.001$ \\
\hline \multicolumn{7}{|l|}{ Chronic medication (None): } \\
\hline One or more & & & 0.12 & $<0.001$ & 0.12 & $<0.001$ \\
\hline \multicolumn{7}{|l|}{ Disease burden (Less than two): } \\
\hline Two or more & & & 0.28 & $<0.001$ & 0.28 & $<0.001$ \\
\hline \multicolumn{7}{|l|}{ Contextual variable } \\
\hline Gender inequality index (GII) & & & & & 0.93 & 0.002 \\
\hline Intercept & -0.20 & $<0.001$ & -1.36 & $<0.001$ & -1.36 & $<0.001$ \\
\hline $\mathrm{N}$ & 48621 & & 48621 & & 48621 & \\
\hline Deviance & 121955 & & 97131 & & 97073 & \\
\hline Intercept variability ( $\%$ of change) ${ }^{a}$ & 0.194 & & $\begin{array}{r}0.086 \\
(56 \%)\end{array}$ & & $\begin{array}{r}0.064 \\
(67 \%)\end{array}$ & \\
\hline Intraclass correlation $^{\mathrm{b}}$ & 0.186 & & 0.116 & & 0.089 & \\
\hline
\end{tabular}

a: \% of change in variability was calculated using the following formula: [(initial variability - end variability) / initial variability] $\mathrm{x}$ 100. b: estimated by [variability intercept / (intercept + residual variability variability)]. Model I: include the activity limitation index by sex without adjustment for other variables. Formula: $A L I_{i j}=\gamma_{00}+\gamma_{10} S e x_{i j}+\mu_{i}+r_{i .}$. Model II: other individual variables were added to the model I (age, educational level, self-perceived health, chronic medication and disease burden), with random intercept without adjustment for the contextual variable. Formula: $A L I_{i j}=\gamma_{00}+\gamma_{10} S e x_{i j}+\gamma_{20} X_{i j}+\ldots+\gamma_{n 0} X_{i j}+\mu_{o j}+r_{i j}$ Model III: Contextual gender inequality variable was added to the model II, with intercepts and inclination (by sex) random among European countries. Formula: $A L I_{i j}=\gamma_{00}+\gamma_{01} G I I_{j}+\gamma_{10} S e x_{i j}+\gamma_{20} X_{i j}+\ldots+\gamma_{n 0} X_{i j}+\mu_{o j}+\mu_{n j} S e x_{i j}+r_{i j}$, where $i=$ individuals $=1, \ldots$, $48621 ; j=$ countries $=1, \ldots, 17 ; X=$ individual variables.

${ }^{*}$ Measure lack of fit between the model and the data, where the larger the deviance, the worse the fit of the model. ${ }^{* *}$ SE: standard error. Level of statistical significance is $\mathrm{p}<0.05$.

Source: SHARE Waves 4/5, 2010-13.

social gender inequalities among countries were significantly associated with greater activity limitations among individuals, with evidence of heterogeneity among countries in the relationship between gender differences and degree of activity limitation present in elderly.

Figure 2 shows gender differences regarding activity limitation in elderly people in European countries. Gender differences were more favourable in Switzerland, the Netherlands, Denmark and Sweden, where the average activity limitation index among women was comparable to the overall average among men in all the European countries evaluated.

\section{Discussion}

Elderly women presented greater activity limitations, with this effect greater among European countries with the highest social gender inequality. Additionally, there is evidence of heterogeneity between countries regarding gender differences in activity limitations. Thus, the individual and contextual effects explained, at least partially, activity limitations in elderly people.

\section{Strengths and limitations}

There are still major challenges regarding the definition and composition of components that make up the measurement of disability. However, 


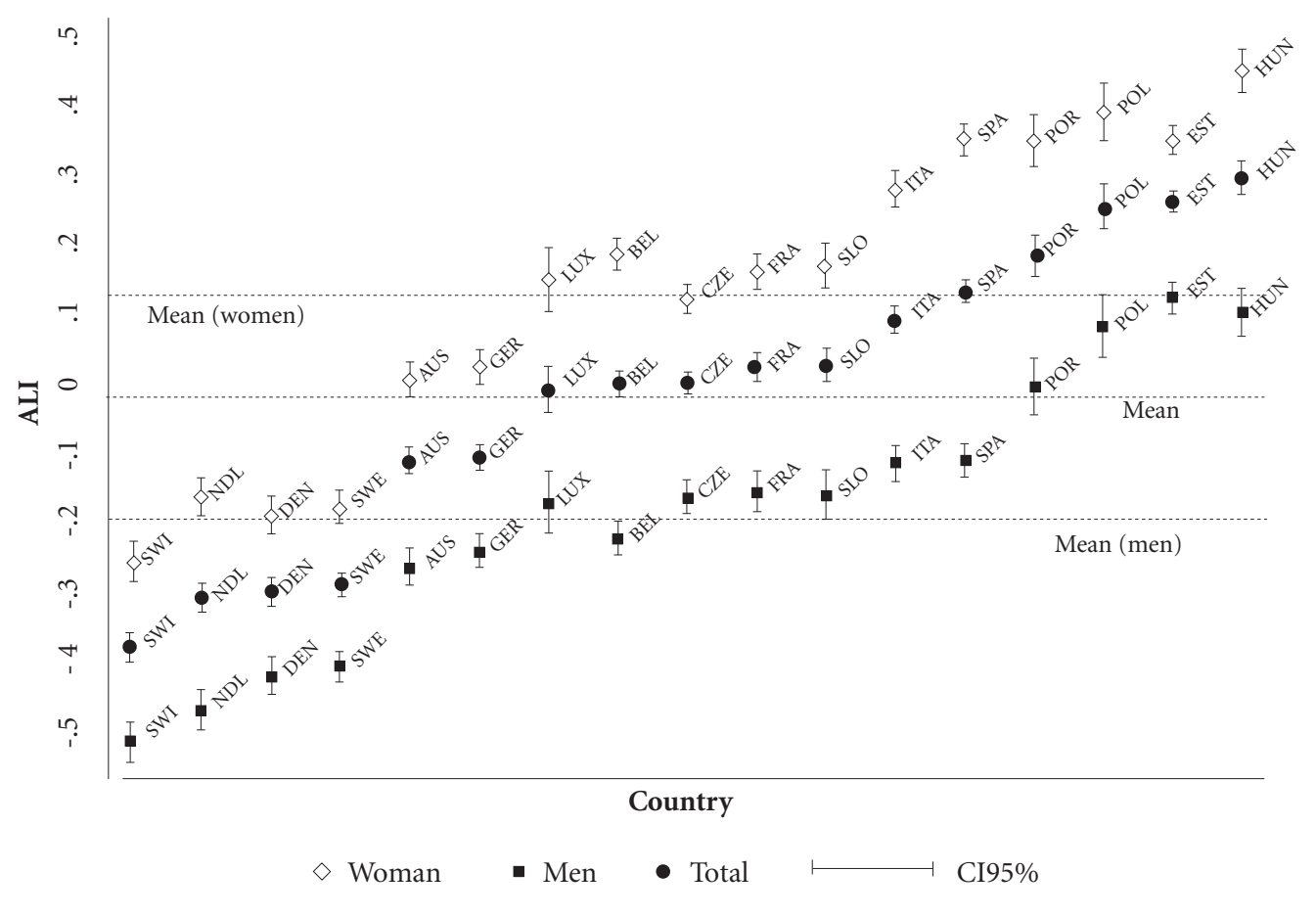

Figure 2. Average activity limitation indexes among elderly people aged 60 or over years. Adjusted average of activity limitation index for men and women, for European countries, considering the $95 \%$ confidence intervals. Source: SHARE Waves 4/5, 2010-13.

activity limitation is one of the components that best reflect the negative aspects of disability ${ }^{25,26}$. In addition, the activity limitation index proposed in this study adds important dimensions and is well defined in global scientific literature $e^{20-22,27}$. These dimensions result in a more complete and robust model for the measurement of features of activity limitations in elderly people than other previous descriptive studies ${ }^{6,28}$.

Obviously, the poor functionality of the elderly is predictive of nonresponse. Individuals who participate in surveys can be less functionally dependent than those who did not participate. However, despite not knowing the magnitude of the impact of non-response rates, we believe the methods used in this study are sufficiently robust to minimize non-response bias.

As far as we are aware, this is the first study that uses item response theory and multilevel analysis to assess the associations between gender differences and the influence of social gender inequality on activity limitation among elderly people, which is a more modern and robust approach than that used by previous descriptive studies $^{20,21}$. Also, the use of multilevel analysis, in addition to adding an ecological approach, can solve the obstacle of using multiple regression models that prevent compliance with the hypothesis of independence between measures of the outcome variable, and provide more accurate estimates for the preconized model. However, the samples have separate selections for each country and reflect a representative sample of their inhabitants, but not the entire population of Europe.

\section{Individual and contextual associated factors}

Other the finding that elderly women generally experience higher rates of morbidity and disability than men, in large part due to their greater life expectancy ${ }^{15}$, the results of this study suggest that social gender inequality should be a central concern for public health policy in Europe. On the other hand, gender differences in years of healthy life can be related to social gender inequalities in the prevalence of activity limitation. In European populations with a long life expectancy, the advantage of women in years of healthy life is small ${ }^{16}$. It should also be mentioned 
that countries with more 'women survivors' do not necessarily correspond to better health conditions ${ }^{29}$. Moreover, men who survive to old age are a selection of the healthiest individuals and are no longer comparable with women of the same age $\mathrm{e}^{30,31}$.

Educational level was established as an important protective factor for activity limitation among elderly people. It has been shown that educational composition is important for the projections of the number of people with functional disability. Future elderly generations are expected to be significantly more educated, with a lower prevalence of functional disability among younger elderly groups (65-74 years old) and a higher rate in older elderly groups (85 or over years old $)^{32}$. In this sense, social policies can create educational opportunities, redistributing income and/or affecting the types of jobs that are available. These policies may affect the nature of social stratification by reducing the number of minimally educated individuals, and then reduce the number of social disadvantages to which individuals are exposed that can lead to disability ${ }^{33,34}$.

Elderly people with the greatest disease burdens and who undergo chronic medication use tend to have more serious activity limitations ${ }^{6}$. Thus, the fact that elderly people are the most medicated age group in society has a direct association with the burden of chronic disease with age. One of the consequences of multiple drug use is the increased risk of adverse reactions, which in turn, can raise the profile of morbidity and mortality in the elderly ${ }^{35,36}$.

It should be added that the demographic and epidemiological transitions that are occurring worldwide are accompanied by the increasing feminization of the elderly population, due to the life expectancy differences between men and women ${ }^{15}$. Although life expectancy differences between men and women are influenced by social factors, there is good evidence that innate biological factors may interact, making a target disparity between them difficult to identify ${ }^{37}$. Moreover, several disability differences between men and women could be at least partially ex- plained by higher comorbidity and depression in women compared to men of a similar age and socioeconomic position ${ }^{14}$.

In the present study, gender differences in relation to the activity limitations were more favourable in Switzerland, Netherlands, Denmark and Sweden. It is known that functional difficulties have been found to be significantly more prevalent among women in these countries, with the relative odds of having functional problems for women ranging from 1.57 in Germany to 2.43 in Spain ${ }^{21}$. Accordingly, a global measure of successful aging ranges from 21\% in Denmark, closely followed by Sweden and Netherlands (17\%), to 3\% in Spain and 2\% in Poland ${ }^{38}$.

In 2013, for comparison, life expectancy in Switzerland was 85 years for women and 81 years for men. Spain, which had a similar life expectancy of 86 years for women and 80 years for men, had one of the worst activity limitation conditions among countries, trailing only Poland, Portugal, Estonia and Hungary ${ }^{39}$. These differences between countries were substantially dependent on social gender inequalities in the present study. According to the social gender inequality index, Slovenia, Switzerland, Germany, Sweden and Denmark had the least gender inequality, while Hungary, Luxembourg, Estonia, Poland, Portugal and Spain were the most unequal, respectively (24). For this reason, analysis of the health situation, health promotion strategies and public rehabilitation policies need to take into account social determinants and social gender inequalities among elderly people.

\section{Conclusions}

The European countries with the greatest gender differences in activity limitations were those with the greatest social gender inequalities, with women presenting a significant disadvantage. However, further research should be conducted using more socioeconomic factors to elucidate the effects of the context of the activity limitations on this population. 


\section{Collaborations}

All authors read and approved the manuscript content. All the authors contributed fundamentally to the accomplishment of this study.

\section{Acknowledgments}

This article uses data from Waves 4 and 5 of the SHARE project, see Börsch-Supan et al. ${ }^{5}$ for methodological details. * SHARE data collection was primarily funded by the European Commission in FP5, FP6 and FP7. This article is part of the doctoral thesis of André Luiz Barbosa Lima, of the Federal University of Rio Grande do Norte - Brazil, with support from the Public Health Agency of Barcelona - Spain. The authors would like to thank the Brazilian Federal Agency for the Support and Evaluation of Graduate Education for the scholarship granted to the doctoral student participating in the study.

\section{References}

1. Eckert KG, Lange MA. Comparison of physical activity questionnaires for the elderly with the International Classification of Functioning, Disability and Health (ICF) - an analysis of content. BMC Public Health 2015; 15(1):249.

2. World Health Organization (WHO). World report on ageing and health. World Report. Geneva: WHO; 2015.

3. Ribeiro LC. Utilização da Classificação Internacional de Funcionalidade, Incapacidade e Saúde (CIF) como ferramenta epidemiológica. Rio de Janeiro: Universidade Federal do Rio de Janeiro; 2012.

4. Altman BM. Definitions, concepts, and measures of disability. Ann Epidemiol 2014; 24(1):2-7.

5. Börsch-Supan A, Kneip T, Litwin H, Myck M, Weber G. SHARE: a European policy device for inclusive ageing societies. In: Börsch-Supan A, Kneip T, Litwin H, Myck M, Weber G, editors. Ageing in Europe - Supporting Policies for an Inclusive Society. Berlin, Boston: De Gruyter; 2015. p. 1-22.

6. Lima ALB, Lima KC. Activity Limitation in the Elderly People and Inequalities in Brazil. OALib [Internet]. 2014 [cited 2014 Sep 21]; 1(4):1-9. Available from: http://www.oalib.com/paper/pdf/3099358

7. Zaslavsky O, Cochrane BB, Thompson HJ, Woods NF, Herting JR, LaCroix A. Frailty: A Review of the First Decade of Research. Biol Res Nurs 2012; 15(4):422-432.

8. McGough, Zumsteg JM. Lifestyle Changes in the Prevention of Mobility Disability. Heal Aging Clin Care Elder 2014; 6(4306):33.

9. Reuter I. Aging, Physical Activity, and Disease Prevention 2012. J Aging Res [Internet]. 2012 Jan [cited 2014 Mar 20]; 2012:1-4. Available from: http:// www.pubmedcentral.nih.gov/articlerender.fcgi?artid $=3523558 \&$ tool $=$ pmcentrez\&rendertype $=$ abstract

10. Ciosak SI, Braz E, Costa MFBNA, Nakano NGR, Rodrigues J, Alencar RA, Rocha ACAL. Senescência e senilidade: novo paradigma na atenção básica de saúde. Rev Esc Enferm USP [Internet]. 2011 Dec [cited 2014 Jun 5]; 45(spe2):1763-1768. Available from: http://www.scielo.br/scielo.php?script=sci_arttext\&pid=S0080-62342011000800022\&lng=pt\&n$\mathrm{rm}=\mathrm{iso} \& \operatorname{lng}=\mathrm{en}$

11. Tak E, Kuiper R, Chorus A, Hopman-Rock M. Prevention of onset and progression of basic ADL disability by physical activity in community dwelling older adults: A meta-analysis. Ageing Res Rev 2013; 12(1):329-338.

12. Sixsmith J, Sixsmith A, Fänge AM, Naumann D, Kucsera C, Tomsone S, Haak M, Dahlin-Ivanoffi S, Woolrych R. Healthy ageing and home: The perspectives of very old people in five European countries. Soc Sci Med 2014; 106:1-9.

13. Borsch-Supan A, Brandt M, Hunkler C, Kneip T, Korbmacher J, Malter F, Schaan B, Stuck S, Zuber S; SHARE Central Coordination Team. Data Resource Profile: The Survey of Health, Ageing and Retirement in Europe (SHARE). Int J Epidemiol 2013; 42(4):992-1001.

14. Zunzunegui MV, Alvarado BE, Guerra R, Gómez JF, Ylli A, Guralnik JM, Imias Research Group. The mobility gap between older men and women: The embodiment of gender. Arch Gerontol Geriatr 2015; 61(2):140-148. 
15. Hosseinpoor AR, Williams JS, Jann B, Kowal P, Officer A, Posarac A, Chatterji S. Social determinants of sex differences in disability among older adults: a multi-country decomposition analysis using the World Health Survey. Int J Equity Health 2012; 11(1):52.

16. Van Oyen H, Nusselder W, Jagger C, Kolip P, Cambois E, Robine J-M. Gender differences in healthy life years within the EU: an exploration of the "health-survival" paradox. Int J Public Health 2013; 58(1):143-155.

17. Alexandre TDS, Corona LP, Nunes DP, Santos JLF, Duarte YADO, Lebrão ML. Gender differences in incidence and determinants of disability in activities of daily living among elderly individuals: SABE study. Arch Gerontol Geriatr 2012; 55(2):431-437.

18. McDermott R, Hatemi PK. Distinguishing sex and gender. PS Polit Sci Polit 2011; 44(1):89-92.

19. World Health Organization (WHO). Gender mainstreaming for health manergers: a practical approach. Geneva: WHO; 2011.

20. Chatterji S, Byles J, Cutler D, Seeman T, Verdes E. Health, functioning, and disability in older adults-present status and future implications. Lancet 2015; 385(9967):563-575.

21. Crimmins EM, Kim JK, Sole-Auro A. Gender differences in health: results from SHARE, ELSA and HRS. Eur $J$ Public Health 2011; 21(1):81-91.

22. Berger N, Van Oyen H, Cambois E, Fouweather T, Jagger C, Nusselder W, Robine JM. Assessing the validity of the Global Activity Limitation Indicator in fourteen European countries. BMC Med Res Methodol 2015; 15:1.

23. Mannheim Research Institute for the Economics of Aging. Survey of Health, Ageing and Retirement in Europe - SHARE: Release guide 2.5.0. Mannheim: Mannheim Research Institute for the Economics of Ageing; 2011.

24. United Nations Development Programme. El indice de desigualdad de género (IDG) [Internet]. 2013 [cited 2016 Jan 15]. Available from: http://hdr.undp.org/es/ content/gender-inequality-index

25. Seidel D, Brayne C, Jagger C. Limitations in physical functioning among older people as a predictor of subsequent disability in instrumental activities of daily living. Age Ageing [Internet] 2011 Jul [cited 2014 Mar 19]; 40(4):463-469. Available from: http:// www.pubmedcentral.nih.gov/articlerender.fcgi?artid $=3114622 \&$ tool $=$ pmcentrez\&rendertype $=$ abstract

26. Loke SC, Lim WS, Someya Y, Hamid TA, Nudin SSH. Examining the Disability Model From the International Classification of Functioning, Disability, and Health Using a Large Data Set of Community-Dwelling Malaysian Older Adults. J Aging Health 2016; 28(4):704725.

27. Dias EG, Duarte YAO, Almeida MHM, Lebrão ML Caracterização das atividades avançadas de vida diária (AAVDS): um estudo de revisão. Rev Ter Ocup da Univ São Paulo [Internet] 2011 Apr 1 [cited 2014 Nov 28]; 22(1):45-51. Available from: http://www.revistas.usp. br/rto/article/view/14119

28. Beltrão KI, Teixeira MP, Parahyba MI, Fletcher P. Capacidade funcional dos idosos: Uma análise dos suplementos Saúde da PNAD com a teoria de resposta ao item. Rio de Janeiro: IBGE; 2013.
29. Escobar Bravo MA, Puga González MD, Martín Baranera M. Análisis de la esperanza de vida libre de discapacidad a lo largo de la biografía: de la madurez a la vejez. Gac Sanit 2012; 26(4):330-335.

30. Andersen-ranberg K, Attias-donfut C, Benson GD, Börsch-supan A. First Results from the Survey of Health, Ageing and Retirement in Europe (2004-2007). Mannheim: Mannheim Research Institute for the Economics of Ageing; 2008.

31. Regan JC, Partridge L. Gender and longevity: Why do men die earlier than women? Comparative and experimental evidence. Best Pract Res Clin Endocrinol Metab 2013; 27(4):467-479.

32. Ansah JP, Malhotra R, Lew N, Chiu CT, Chan A, Bayer S, Matchar DB. Projection of young-old and old-old with functional disability: Does accounting for the changing educational composition of the elderly population make a difference? PLoS One 2015; 10(5):e0126471.

33. Souza Braga L, Lima-Costa MF, Cesar CC, Macinko J. Social Inequalities on Selected Determinants of Active Aging and Health Status Indicators in a Large Brazilian City (2003-2010). J Aging Health 2016; 28(1):180-196.

34. Tyrovolas S, Koyanagi A, Olaya B, Ayuso-Mateos JL, Miret M, Chatterji S, Tobiasz-Adamczyk B, Koskinen $\mathrm{S}$, Leonardi M, Haro JM. The role of muscle mass and body fat on disability among older adults: A cross-national analysis. Exp Gerontol 2015; 69:27-35.

35. Arruda GO, Lima SCDS, Renovato RD. The use of medications by elderly men with polypharmacy: representations and practices. Rev Lat Am Enfermagem 2013; 21(6):1337-1344.

36. Hubbard RE, O’Mahony MS, Woodhouse KW. Medication prescribing in frail older people. Eur J Clin Pharmacol [Internet]. 2013 Mar [cited 2013 Aug 7]; 69(3):319-326. Available from: http://www.ncbi.nlm. nih.gov/pubmed/22965651

37. Hambleton IR, Howitt C, Jeyaseelan S, Murphy MM, Hennis AJ, Wilks R, Harris EN4, MacLeish M5, Sullivan L5; U.S. Caribbean Alliance for Health Disparities Research Group (USCAHDR). Trends in Longevity in the Americas: Disparities in Life Expectancy in Women and Men, 1965-2010. PLoS One 2015; 10(6):e0129778.

38. Hank K. How "Successful" Do Older Europeans Age? Findings From SHARE. J Gerontol B Psychol Sci Soc Sci 2011; 66(2):230-236

39. Banco Mundial. Esperanza de vida al nacer, mujeres, hombres y total (años) [Internet]. 2013 [cited 2015 Nov 2]. Available from: datos.bancomundial.org/indicador/

Artigo apresentado em 18/05/2016

Aprovado em 19/08/2016

Versão final apresentada em 21/08/2016 